Precision Cleaning Titanium Components

Federal Manufacturing \& Technologies

T. E. Hand and

G. W. Bohnert

KCP-613-6301

Published February 2000

Final Report/CRADA Project Accomplishments Summary

CRADA Number 98KCP1058

Approved for public release; distribution is unlimited.

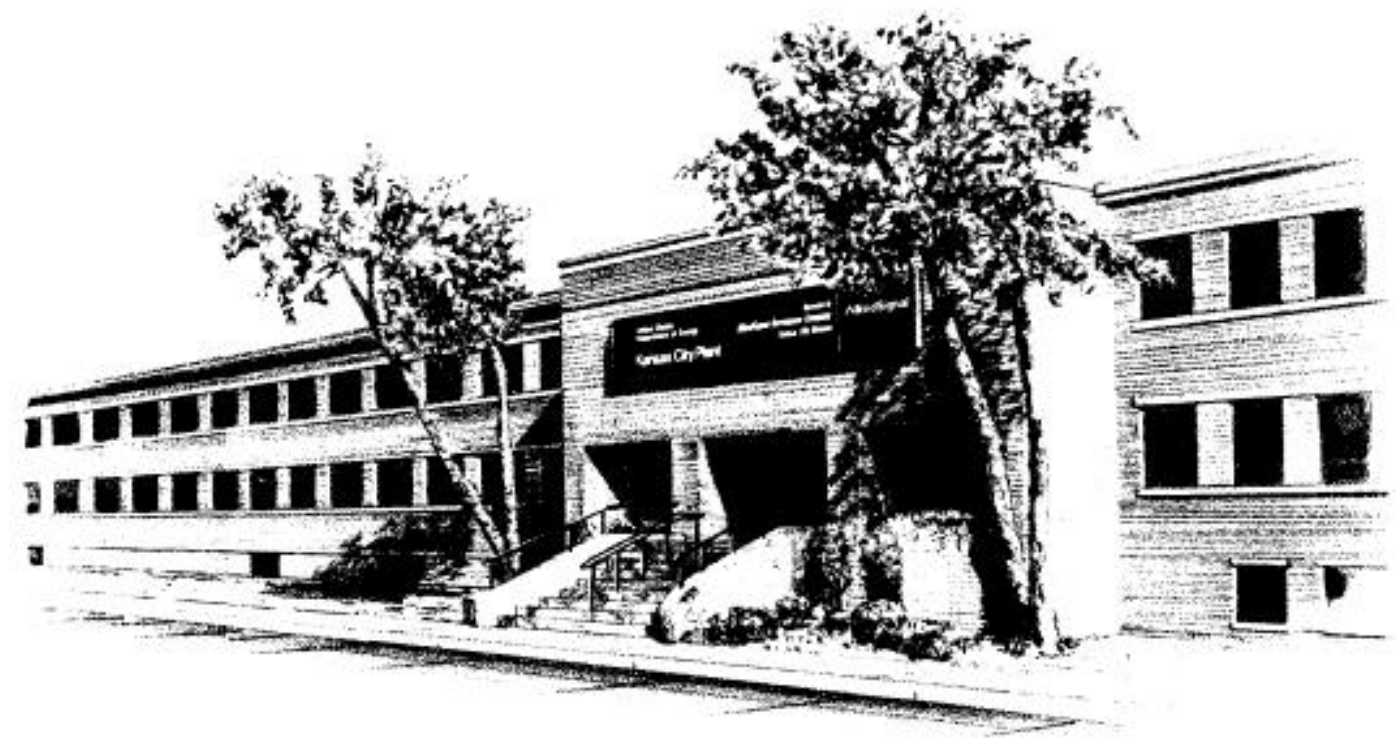

Prepared Under Contract Number DE-ACO4-76-DP00613 for the

United States Department of Energy

\title{
DISCLAIMER
}

This report was prepared as an account of work sponsored by an agency of the United States

Government. Neither the United States Government nor any agency thereof, nor any of their employees, 
makes any warranty, express or implied, or assumes any legal liability or responsibility for the accuracy, completeness, or usefulness of any information, apparatus, product, or process disclosed, or represents that its use would not infringe privately owned rights. Reference herein to any specific commercial product, process, or service by trade names, trademark, manufacturer, or otherwise, does not necessarily constitute or imply its endorsement, recommendation, or favoring by the United States Government or any agency thereof. The views and opinions of authors expressed herein do not necessarily state or reflect those of the United States Government or any agency thereof.

Printed in the United States of America.

This report has been reproduced from the best available copy.

Available to DOE and DOE contractors from the Office of Scientific and Technical Information, P. O. Box 62, Oak Ridge, Tennessee 37831; prices available from (865) 576-8401, FTS 626-8401.

Available to the public from the National Technical Information Service, U. S. Department of Commerce, 5285 Port Royal Rd., Springfield, Virginia 22161, (703) 487-4650.

Honeywell

Federal Manufacturing

$\&$ Technologies

P. O. Box 419159

A prime contractor with the United States

Kansas City, Missouri

Department of Energy under Contract Number

64141-6159

DE-ACO4-76-DP00613.

KCP-613-6301

Distribution Category UC-706

Approved for public release; distribution is unlimited. 


\section{PRECISION CLEANING TITANIUM COMPONENTS}

T. E. Hand and

G. W. Bohnert

Published February 2000

Final Report/Project Accomplishments Summary

CRADA Number 98KCP1058

\section{Precision Cleaning Titanium Components}

Project Accomplishments Summary

CRADA Number 98KCP1058

Date: December 1999

Revision: 1

A. Parties

The project is a relationship between

Honeywell FM\&T

Pratt and Whitney

2000 E $95^{\text {th }}$ Street

400 Main Street

PO Box 419159

East Hartford, CT 06108

Kansas City, MO 64141-6159 


\section{B. Background}

Pratt and Whitney (P\&W) manufactures jet engines for commercial and military applications; Honeywell Federal Manufacturing \&Technologies (FM\&T) manufactures non-nuclear components and assemblies for nuclear weapons. Both companies share common strengths in the production of high reliability components for aerospace and military sectors.

Clean surfaces are paramount to the service life of diffusion bonded titanium assemblies. High reliability applications, such as jet engine compressor blades, require ultra clean surfaces to obtain parent metal bond strengths. Prior to diffusion bonding, one of the preparation processes for the base metals is immersion in a nitric-hydrofluoric acid solution. Pratt and Whitney, being an environmentally concerned corporation, wanted to eliminate this material from its manufacturing process. During this CRADA, the Pratt and Whitney/Honeywell team investigated cleaning processes to replace the nitric-hydrofluoric acid etch process.

\section{Description}

Clean bond surfaces are critical to the operation of diffusion bonded titanium engine components. These components can be contaminated with machining coolant, shop dirt, and fingerprints during normal processing and handling. These contaminants must be removed to achieve acceptable bond quality.

As environmental concerns become more important in manufacturing, elimination of the use of hazardous materials is desired. For this reason, another process (not using nitric-hydrofluoric acid solution) to clean titanium parts before bonding was sought.

Initial cleaning trials were conducted at Honeywell to screen potential cleaning techniques and chemistries. During the initial cleaning process screening phase, Pratt and Whitney provided Honeywell with machined 3" x 3" x 1" titanium test blocks. These test blocks were machined with a water-based machining coolant and exposed to a normal shop environment and handling. (Honeywell sectioned one of these blocks into smaller samples to be used for additional cleanliness verification analyses.) The sample test blocks were ultrasonically cleaned in alkaline solutions and AUGER analysis was used by Honeywell FM\&T to validate their cleanliness. This information enabled selection of final cleaning techniques and solutions to be used for the bonding trials.

To validate Honeywell's AUGER data and to verify the cleaning processes in actual situations, additional sample blocks were cleaned (using the chosen processes) and then bonded. The bond quality of the test blocks was analyzed according to Pratt and Whitney's requirements. The Charpy impact testing was performed according to ASTM procedure \#E-23. Bond quality was determined by examining metallographic samples of the bonded test blocks for porosity along the bondline.

Discussion of Bonding Results

Of the six sets of bonded test blocks cleaned by Honeywell, four met Pratt and Whitney's 
requirements for bond quality and Charpy impact These results were consistent with the results obtained from four of the five sets of bonded blocks cleaned by two independent equipment suppliers. It was noted that the surface finish of some of the test blocks was slightly rougher than the others and may have contributed to the lower bond quality values. Two full-scale parts were also ultrasonically cleaned and bonded. The Charpy impact results and bond quality obtained from these parts substantiated the results from the cleaning processes on the sample bonded test blocks.

D.

E. Expected Economic Impact

Pratt and Whitney's goals for this CRADA were that an environmentally friendly "pre-diffusion-bonding" process be identified; they also desired that this process have low capital investment cost and use safer materials. Based on the acceptable results of the majority of the test blocks that were processed by Honeywell, two equipment suppliers, and the actual cleaning trials of two full-scale parts, the CRADA project has verified that ultrasonic cleaning of titanium components prior to diffusion bonding is a viable alternative to acid pickling.

Some of the benefits to be derived include identification of an effective and environmentally friendly cleaning process. Additionally, Pratt and Whitney is expected to realize a potential reduction in manufacturing costs and improved bond quality if the cleaning process is implemented. Lower cost of manufacturing can result in savings to its customers. Safer processes are better for manufacturing and engineering personnel and the environment.

E.

F. Benefits to DOE

An adaptation of the CRADA-derived and developed cleaning process is being used for production parts at Honeywell. Working with Pratt and Whitney enabled the sharing of the expertise of both companies to achieve a common goal. Honeywell was able to use the results of the bonding studies to select appropriate cleaning solutions and methods for titanium. Pratt and Whitney was able to use the test data from the Honeywell laboratories to screen potential cleaning solutions and select a new process.

F.

G. Industry Area

This project had direct applications in the aerospace industry, and information derived from it will be useful to other industries doing high reliability bonding of materials.

G.

H. Project Status 
The project was completed as planned

H. Point of Contact for Project Information

Ken Bauer

US Department of Energy

Kansas City Area Office

PO Box 410202

Kansas City, MO 64141-0202

Telephone: (816) 997-3917
George Bohnert

Honeywell FM\&T

PO Box 419159

Kansas City, MO 64141-6159

Telephone: (816) 997-5069

Fax (816) 997-2049

Fax: (816) 997-5059

I.

II. Company Size and Point of Contact

Pratt and Whitney is a division of United Technologies Corporation. United Technologies employs 170,000 worldwide and had sales of 24 billion dollars in 1997. George Jeong was the principal investigator and contact at Pratt and Whitney. George's telephone number is 860-565-9593 and his fax number is 860-565-5611. George Bohnert and George Jeong can provide any non-proprietary data and comments regarding the project.

\section{J.}

K. Project Examples

Pratt and Whitney is evaluating test data and reviewing manufacturing and quality requirements to verify that the new cleaning process developed from this CRADA meets company strategic goals.

K.

L. Technology Commercialization

None

L. Release of Information

I have reviewed the attached Project Accomplishment Summary prepared by Honeywell 
FM\&T and agree that the information about our CRADA may be released for external distribution.

Original signed by

Name: Lorin S. Sodell

Organization: Manufacturing

Engineering,

Title: Chief, Manufacturing Engineering
7 Jan 00

Date

Operations 